
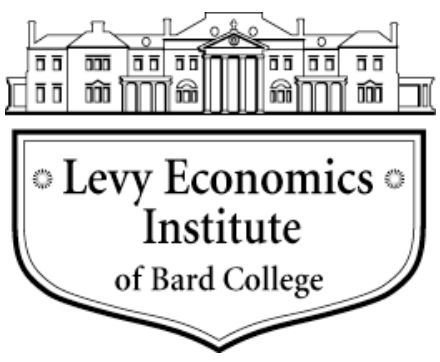

Working Paper No. 749

\title{
Weak Expansions: A Distinctive Feature of the Business Cycle in Latin America and the Caribbean
}

by

\author{
Esteban Pérez Caldentey, Daniel Titelman, and Pablo Carvallo* \\ Economic Commission for Latin America and the Caribbean \\ Financing for Development Division
}

January 2013

\begin{abstract}
* The opinions here expressed are the authors' own and may not coincide with those of the Economic Commission for Latin America and the Caribbean (ECLAC). An earlier version of this paper was presented at the ECLAC workshop "Policies for Sustained Growth with Equality," Santiago, Chile, October 29-30, 2012. We wish to thank the participants for the useful comments received during the presentation and discussion of the paper, and, in particular, Cecilia Vera for very valuable suggestions for improving the paper's arguments and coherence. We are also grateful to John Rand and Finn Tarp (University of Copenhagen) for sharing the computer codes for the Bry-Boschan algorithm procedure in Mat Lab.
\end{abstract}

The Levy Economics Institute Working Paper Collection presents research in progress by Levy Institute scholars and conference participants. The purpose of the series is to disseminate ideas to and elicit comments from academics and professionals.

Levy Economics Institute of Bard College, founded in 1986, is a nonprofit, nonpartisan, independently funded research organization devoted to public service. Through scholarship and economic research it generates viable, effective public policy responses to important economic problems that profoundly affect the quality of life in the United States and abroad.

\author{
Levy Economics Institute \\ P.O. Box 5000 \\ Annandale-on-Hudson, NY 12504-5000 \\ http://www.levyinstitute.org
}

Copyright (C) Levy Economics Institute 2013 All rights reserved

ISSN 1547-366X 


\begin{abstract}
Using two standard cycle methodologies (classical and deviation cycle) and a comprehensive sample of 83 countries worldwide, including all developing regions, we show that the Latin American and Caribbean cycle exhibits two distinctive features. First, and most important, its expansion performance is shorter and, for the most part, less intense than that of the rest of the regions considered; in particular, that of East Asia and the Pacific. East Asia's and the Pacific's expansions last five years longer than those of Latin American and the Caribbean, and its output gain is 50 percent greater. Second, the Latin American and Caribbean region tends to exhibit contractions that are not significantly different from those other regions in terms of duration and amplitude. Both these features imply that the complete Latin American and Caribbean cycle has, overall, the shortest duration and smallest amplitude in relation to other regions. The specificities of the Latin American and Caribbean cycle are not confined to the short run. These are also reflected in variables such as productivity and investment, which are linked to long-run growth. East Asia's and the Pacific's cumulative gain in labor productivity during the expansionary phase is twice that of Latin American and the Caribbean. Moreover, the evidence also shows that the effects of the contraction in public investment surpass those of the expansion, leading to a declining trend over the entire cycle. In this sense, we suggest that policy analysis needs to increase its focus on the expansionary phase of the cycle. Improving our knowledge of the differences in the expansionary dynamics of countries and regions can further our understanding of the differences in their rates of growth and levels of development. We also suggest that, while the management of the cycle affects the short-run fluctuations of economic activity and therefore volatility, it is not trend neutral. Hence, the effects of aggregate demand management policies may be more persistent over time, and less transitory, than currently thought.
\end{abstract}

Keywords: Latin American Business Cycle; Classical Cycle; Deviation Cycle; Expansions; Trend and Cycle; Productivity; Investment

JEL Classifications: E32, F44, O11, O54 


\section{INTRODUCTION}

In this paper, we use the "classical cycle" and "deviation cycle" standard methodologies to characterize the business cycle for Latin American and the Caribbean in relation to that of other regions of the world, placing the focus of the comparison on East Asia and the Pacific. We characterize the complete cycle and its phases (contraction/expansion) in terms of duration and amplitude for a sample of 83 countries, 44 of which belong to the different developing regions of the world and 39 of which are classified as high income economies. ${ }^{1}$ The analysis is undertaken using quarterly data covering the period 1989-2012. ${ }^{2}$

The majority of the results obtained are robust to the use of both the "classical cycle" and "deviation cycle" methodologies. These show that the Latin American and Caribbean cycle displays two distinct features. On the one hand, and most importantly, the Latin American and Caribbean region has weaker expansions relative to other regions of the world. On the other hand, Latin America and the Caribbean have contractions whose duration and amplitude do not differ significantly from those of other developing countries. As a result, the full cycle of expansions and contractions exhibits, on a general basis, the shortest duration and smallest amplitude among all regions.

The dynamics of the Latin American and Caribbean cycle are not confined exclusively to short-run analysis. These are also reflected in the behavior of variables such as productivity and investment, which are generally identified as determinants of long-run growth.

In particular, the tenuous nature of the expansionary phase of the cycle is reflected in the fact that productivity growth in Latin America and the Caribbean during that cycle phase tends to be below that of other developing regions, notably East Asia and the Pacific. Moreover, the evidence suggests that, as a general rule, the growth of public capital formation during the expansion is unable to supersede its contraction in the downward phase of the cycle, leading to a decline in the level of public investment during the complete business cycle.

The paper is divided into six sections. The first underscores the importance of studying cyclical behavior, especially in the case of Latin America and the Caribbean. The second section briefly explains the methodologies and describes the dataset used in the paper. The third, fourth,

\footnotetext{
${ }^{1}$ In our categorization of developing economies we include low and middle income economies following the World Bank Classification.

${ }^{2}$ Data for the period 1980 to 2012 was not available for all the countries included in our study. See the annex for the countries included and time period covered.
} 
and fifth sections concentrate on the stylized facts of the Latin American and Caribbean cycle. The sixth section discusses, albeit in a preliminary fashion, the linkages between the cycle and long-run outcomes. The last section concludes with a reflection on cycle analysis and pinpoints directions for further research on the topic.

\section{WHY WE SHOULD NOT GIVE SHORT SHRIFT TO THE CYCLE}

Over the past three decades, the economic performance of Latin America and the Caribbean region has been characterized by an increasing degree of volatility in terms of output and investment behavior (among other variables). Moreover, volatility in Latin America and the Caribbean has tended to surpass that of other regions of the world (Titelman, Pérez Caldentey, and Minzer 2008; Calderón and Fuentes 2012; ECLAC 2002, 2012).

At the same time, Latin America and the Caribbean have experienced lower long-run growth in relation to other regions. Table 1 shows the evolution of GDP per capita growth for Latin America and the Caribbean, the Organisation for Economic Co-operation and Development (OECD) member states (high income economies), and selected developing regions of the world for the period 1970-2011.

The evidence indicates that Latin America and the Caribbean had the highest levels of GDP per capita growth in the 1970s in relation to other regions, with the exception of East Asia and the Pacific. Thereafter, the region has registered one of the lowest rates of growth of GDP per capita in relation to other developing regions for most of the periods under consideration (1981-1990, 1991-2000, 2001-2009, and 2001-2011). Moreover, the growth differential between Latin America and the Caribbean and other regions (such as the case of East Asia and the Pacific) has widened over time (see Table 1).

The most recent period of expansion (2003-2007) does not constitute an exception to this observed trend. During this time, Latin America and the Caribbean experienced the highest average rate of growth in over three decades. The regional average per capita growth rate reached 3.7 percent, surpassing not only that of the 1980s lost decade and that registered during the free market structural reform era (1991-2000; 1.4 percent), but also that of the 1970s (3.2 percent).

However, on a comparative basis, Latin America and the Caribbean's performance was by no means an exceptional one. In fact, the regional rate of growth remained significantly 
below those of East Asia and the Pacific (9.3 percent), Europe and Central Asia (7.4 percent), and South Asia (6.6 percent).

Table 1 GDP per capita growth by region/income grouping, 1971-2011

\begin{tabular}{|l|l|l|l|l|l|l|l|}
\hline & $\begin{array}{l}\text { East } \\
\text { Asia \& } \\
\text { Pacific }\end{array}$ & $\begin{array}{l}\text { Europe \& } \\
\text { Central } \\
\text { Asia }\end{array}$ & $\begin{array}{l}\text { High income: } \\
\text { OECD }\end{array}$ & $\begin{array}{l}\text { Latin } \\
\text { America \& } \\
\text { Caribbean }\end{array}$ & $\begin{array}{l}\text { Middle East } \\
\text { \& North } \\
\text { Africa }\end{array}$ & $\begin{array}{l}\text { South } \\
\text { Asia }\end{array}$ & $\begin{array}{l}\text { Sub- } \\
\text { Saharan } \\
\text { Africa }\end{array}$ \\
\hline $1971-1980$ & 4.5 & $\ldots$ & 2.7 & 3.2 & 2.7 & 0.7 & 0.9 \\
\hline $1981-1990$ & 5.7 & -1.7 & 2.7 & -0.8 & 0.2 & 3.0 & -0.9 \\
\hline $1991-2000$ & 7.1 & -1.7 & 1.9 & 1.6 & 1.8 & 3.2 & -0.3 \\
\hline $\mathbf{2 0 0 3 - 2 0 0 7}$ & $\mathbf{9 . 3}$ & $\mathbf{7 . 4}$ & $\mathbf{1 . 9}$ & $\mathbf{3 . 7}$ & $\mathbf{3 . 3}$ & $\mathbf{6 . 6}$ & $\mathbf{3 . 0}$ \\
\hline $2001-2011$ & 8.2 & 4.7 & 0.9 & 2.2 & 2.6 & 5.3 & 2.1 \\
\hline
\end{tabular}

Source: World Development Indicators and Global Finance, World Bank (2012)

Part of the explanation of both the high degree of volatility and low level of long-run growth lies in the specific features of the Latin American and Caribbean cycle.

Cycle fluctuations and their characteristics define the pattern and nature of volatility. Moreover, in spite of the fact that cycle fluctuations are traditionally associated with a shortperiod context, these can also impinge on long-run growth by their effects on investment and productivity, among other variables.

In this regard, the cycle itself as well as the policies designed and implemented to confront and manage its fluctuations is not trend-neutral. From here follows the importance of analyzing, characterizing, and identifying the distinguishing features of the Latin American and Caribbean cycle in relation to other developing regions. In the sections that follow, we place particular focus on the comparison with East Asia and the Pacific, which is often used for this region as a benchmark for assessing social and economic progress and development.

\section{THE METHODOLOGICAL APPROACH}

Business cycles are generally defined as periodic patterns in the fluctuations of macroeconomic variables including output, unemployment, consumption, investment, and prices over months or 
years. ${ }^{3}$ In this sense, the cycle can be viewed as a series of turning points (peaks and troughs) with alternating phases of expansion and contraction.

Currently there are two main approaches to the analysis of the business cycle, the classical cycle and deviation cycle. ${ }^{4}$ The former defines the cycle as a series of turning points in the level of real aggregate economic activity. For the latter, the cycle is defined in terms of the deviations of real aggregate economic activity from its trend (or potential output). Both methodologies can be used to characterize the cycle in terms of duration and intensity. However, due to methodological differences, the deviation cycle produces longer contractions than the classical cycle and fails to capture the asymmetry of the cycle. ${ }^{5}$

In this paper, we use both methodologies to show that our results are not dependent on any given approach. Moreover, to further strengthen our arguments, both methodologies are applied on a comprehensive dataset comprising 83 economies worldwide and including all developing regions.

\subsection{The Deviation Cycle and the Classical Cycle}

The deviation cycle, also known as the growth cycle, sees the cycle as a set of serially correlated deviations of a series from its trend (Lucas 1987; Sargent 1987; Blanchard and Fisher 1989; Kydland and Prescott 1990; Zarnowitz 1992). According to this approach, any series in levels $\left(y_{t}\right)$ can be decomposed into a trend $\left(\mu_{t}\right)$ and cycle component $\left(\psi_{t}\right)$. That is,

$$
\text { (1) } y_{t}=\mu_{t}+\psi_{t}
$$

\footnotetext{
${ }^{3}$ The standard definition is provided in the classical text by Burns and Mitchell (1946, p. 3): "Business Cycles are a type of fluctuation found in the aggregate economic activity of nations that organize their work mainly in business enterprises: a cycle consists of expansions occurring at about the same time in many economic activities, followed by similarly general recessions, and revivals which merge into the expansion phase of the next cycle; this sequence of changes is recurrent but not periodic; in duration business cycles vary from more than one year to ten to twelve years; they are not divisible into shorter cycles of similar character with amplitudes approximating their own." See Medio (2008) for a review of business cycle theories.

${ }^{4}$ Other approaches include the rocking horse view championed by Ragnar Frisch and the growth rate cycle. Frisch's approach built on Knut Wicksell's and distinguished between the propagation and the impulse problem. As he put it: "There need not be any synchronism between the initiating force or forces and the movement of the swinging system. This fact has frequently been overlooked in economic cycle analysis. If a cyclical variation is analyzed from the point of view of a free oscillation, we have to distinguish between two fundamental problems: first, the propagation problem; second the impulse problem" (Frisch 1933, p. 171). See Pagan (2003) and Zambelli (1997) for a critique. The growth refers to fluctuations in the growth rate of economic activity. Within this approach, an expansion/recession is defined as a prolonged increase (decline) in economic activity. The Economic Cycle Research Institute (ECRI) provides growth rate chronologies (http://www.businesscycle.com). According to ECRI, the rate of growth is computed as $\left[\frac{y t}{\sum_{j=0}^{s-1} y_{t-j} / s}\right]^{\frac{2 s}{(s+1)}}$ where $\mathrm{s}$ is the number of observations. See Artis,
}

Maecrellin, and Proietti (2003).

${ }^{5}$ This follows Pagan (2003). 
Assuming that $\left(y_{t}\right)$ is expressed in logarithm and that it admits the log-additive decomposition, growth (or the change in the logarithm of $y_{t}$, i. e., $\Delta y_{t}$ ) can then be decomposed in turn into a trend and a cycle component,

$$
\text { (2) } \Delta y_{t}=\Delta \mu_{t}+\Delta \psi_{t}
$$

Within this approach, an expansion occurs when growth of the series in question is above trend, i.e., $\Delta y_{t}>\Delta \mu_{t}$. Similarly, a recession occurs when the growth of a series is below trend, i.e., $\Delta y_{t}<\Delta \mu_{t}$. A central aspect of this approach is the construction of the permanent component of the series, which is usually derived using some type of filter. ${ }^{6}$ On the basis of the above, deviation cycles are then constructed.

The classical cycle views the cycle as a set of turning points of a time series, representing the level of aggregate economic activity without consideration to a trend (Burns and Mitchell 1946; Harding and Pagan 2002b, 2005; Pagan 2003). The inflection points of the series are then used as a basis to analyze the cycle in terms of a series of indicators such as the duration and intensity of an expansion (trough-to-peak) and a contraction (peak-to-trough), and the degree of coincidence between two given time series. Central to this approach is the identification of the turning points of a series.

The turning points of a series are usually identified using the Bry-Boschan algorithm (1971) developed originally for monthly data and adapted to deal with quarterly observation by Harding and Pagan (2002a). ${ }^{7}$ The algorithm consists in identifying local maxima and minima for a given series following a logarithmic transformation using specific censoring rules (Bry and Boschan 1971; Du Plessis 2006; Male 2009).

These include the specification of two quarters for a minimum duration for a single phase, and a minimum duration of five quarters for a complete cycle (Harding and Pagan 2002a). The peak for a series $y_{t}$ is found when $y_{t}$ is greater than $y_{t \mp k}$ for $k=1$,2. Similarly, the trough for a series $y_{t}$ is found when $y_{t}$ is less than $y_{t \mp k}$ for $k=1,2$. The algorithm excludes the occurrence of two successive peaks or troughs.

Two other alternative algorithms used in the literature on business cycles to determine turning points are the Calculus and the Okun rule. The Calculus rule identifies a recession (expansion) when the rate of growth of GDP is negative (positive) for at least one quarter. The

\footnotetext{
${ }^{6}$ Including the band-pass (i.e., Baxter and King), Hodrick-Prescott, and model-based filters.

7 The majority of recent classical cycle analyses use the Bry-Boschan algorithm for identifying turning points.
} 
Okun rule extends the time domain of an expansion or recession to two quarters (see Pagan 2003; see, also, Table 2). ${ }^{8}$

Table 2 Algorithms for the identification of turning points in classical cycles

\begin{tabular}{|l|l|l|}
\hline Algorithms & Peak & Trough \\
\hline Bry-Boschan & $\left\{\left(y_{t-2}, y_{t-1}\right)<y_{t}>\left(y_{t+1}, y_{t+2}\right)\right\}$ & $\left\{\left(y_{t-2}, y_{t-1}\right)>y_{t}<\left(y_{t+1}, y_{t+2}\right)\right\}$ \\
\hline Calculus & $\left\{y_{t-1},<y_{t}>y_{t+1},\right\}$ & $\left\{y_{t-1},>y_{t}<y_{t+1}\right\}$ \\
\hline Okun & $\left\{\left(\Delta y_{t-1}, \Delta y_{t}\right)>0 ;\left(\Delta y_{t+1}, \Delta y_{t+2}\right)<0\right\}$ & $\left\{\left(\Delta y_{t-1}, \Delta y_{t}\right)<0,\left(\Delta y_{t+1}, \Delta y_{t+2}\right)>0\right\}$ \\
\hline
\end{tabular}

Source: On the basis of Pagan 2003; Harding 2008; Wecker 1970.

Once the turning points in the series are identified, the business cycle can be characterized in terms of duration and intensity. The duration (D) of an expansion is defined as the ratio the total number of quarters of expansion to the total number of peaks. That is,

$$
\text { (3) } D=\frac{\sum_{t=1}^{T} S_{t}}{\sum_{t=1}^{T-1}\left(1-S_{t+1}\right) S_{t}}
$$

where $\mathrm{S}$ is a binary variable that takes a 1 during an expansion and 0 during a contraction. ${ }^{9}$ The numerator in (1) $\left(\sum_{t=1}^{T} S_{t}\right)$ denotes the total duration of expansions and the denominator $\left(\sum_{t=1}^{T-1}\left(1-S_{t+1}\right) S_{t}\right)$ measures the number of peaks in the series.

For its part, the intensity or amplitude (A) of the expansion is measured as the ratio of the total change in aggregate economic activity to the total number of peaks. That is,

$$
\text { (4) } A=\frac{\sum_{t=1}^{T} S_{t} \Delta Y_{t}}{\sum_{t=1}^{T-1}\left(1-S_{t+1}\right) S_{t}}
$$

where $\mathrm{Y}$ is a measure of economic activity (GDP in our cases) and the numerator in (4) $\left(\sum_{t=1}^{T} S_{t} \Delta Y_{t}\right)$ is the total change in economic activity.

Using Harding and Pagan's triangle analogy, the ratio of the amplitude to the duration can be thought of as a measure of steepness. Also, the cumulative change (CC) in the expansion (contraction) can then be found by multiplying the product of the duration (D) and the intensity (A) of the expansion (contraction) by 0.5 , i.e, $\mathrm{CC}=0.5 *\left(\mathrm{D}^{*} \mathrm{~A}\right)$.

Due to the differences in their definition of the cycle, the application of a similar methodology (say, that of the Bry-Boschan algorithm, as is done throughout this paper) to

\footnotetext{
${ }^{8}$ As can be seen from the definition, the Calculus criterion tends to produce a higher frequency of expansions and contractions than the Bry-Boschan or the Okun criteria, simply because its threshold to identify whether a series is in a contraction or an expansion phase is comparatively less demanding. It requires only one observation where the growth of the series in question is negative $\left(\Delta y_{t}<0\right)$, whereas the Bry-Boschan and Okun require two consecutive observations.

${ }^{9}$ Similarly, the duration and amplitude for contractions are computed using $c_{i, t}=1-s_{i . t}$.
} 
identify the turning points in the classical and deviation cycle analyses can produce different characterizations of the cycle. Two of these differences are worth noting.

First, the classical cycle tends to produce shorter contractions than the deviation cycle. This is due to the fact that a downturn in the classical cycle occurs when $\Delta y_{t}<0$. Contrarily, in the deviation cycle, a downturn occurs when $\Delta y_{t}-\Delta \mu_{t}<0$. This implies that a downward phase in a deviation cycle can contain several classical cycle recession episodes (see Artis, Maecrellin and Proietti 2003; Pagan 2003). ${ }^{10}$

Second, the deviation cycle fails to capture the asymmetry between the contraction and the expansion phases. This responds to the fact that the deviation cycle is defined as a series of correlated deviations from the trend. As a result, the cyclical component is stationary, and this implies that the long-run average of the cyclical component is zero. ${ }^{11}$ That is, the positive and negative deviations will tend to cancel out over time. Thus by virtue of its own definition, the positive and negative cyclical deviations from the trend are symmetric.

Cognizant of these differences, we assess the results of each of these criteria and approaches on the basis of their own terms and logic. It is a question of identifying stylized facts pertaining to the specific behavior of the Latin America and Caribbean cycles in comparison to other regions that are robust with regard to the use of different statistical methodologies.

\subsection{The Dataset}

In order to ensure adequate geographical representation, a comprehensive sample of 83 countries was used in the analysis. Of these, 44 are emerging market economies and 39 are

\footnotetext{
${ }^{10}$ A deviation cycle considers as a recession not only the case in which $\Delta y_{t}<0$, as in the classical cycle, but also when $\Delta y_{t}>0$ and $\left|\Delta \mu_{t}\right|>\left|\Delta y_{t}\right|$. In this sense, these methods are not strictly comparable. Pagan (2003, p. 17) states that: "...those statistics gathered about the business cycle by Burns and Mitchell and the NBER have no immediate relevance to those of the [the deviation cycle]." In this paper, the aim of using different methodologies is mainly to show that the results obtained are robust to different methodologies. Even though we make comparisons in the text among methodologies, the guiding principle is to assess them for their own logic and development.

${ }^{11}$ In the deviation cycle, the cyclical component is stationary. Stationarity is not an issue in the classical cycle approach.
} 
considered developed economies (i.e., high-income economies). ${ }^{12}$ The analysis is undertaken using quarterly data for the period 1989-2012. ${ }^{13}$

The sample of emerging market economies comprise 21 countries belonging to Latin America and the Caribbean, 5 to East Asia and the Pacific, 11 to Europe and Central Asia, 3 to the Middle East and North Africa, 1 to South Asia, and 3 to Sub-Saharan Africa. The subsample of high-income economies includes European (23), Asian (4), North American (2), Caribbean (2), and other countries. ${ }^{14}$

As can be seen from Table 3 below, our dataset is (in comparison to other analyses on the subject) one of the largest and most representative at the regional and also at the Latin American and Caribbean sub-regional level. In contrast to other studies on the subject, it includes most countries of South and Central America as well as Caribbean economies, thus avoiding introducing a sub-regional bias in the results obtained. ${ }^{15}$

\footnotetext{
${ }^{12}$ As noted above, our analysis includes only low- and upper- and low-middle-income countries in the category of emerging market economies. This marks a difference between our approach and other studies that tend to include countries such as Singapore and Hong Kong as emerging market economies, and thus end up comparing the performance of middle-income countries, such as those of Latin America, with both middle-income and highincome countries indistinctively.

${ }^{13}$ Data for the period 1989-2012 was not available for all countries. See the appendix for a detailed overview of the countries included and the respective time period. Quarterly GDP was used for all countries in the sample, with the only exception of Barbados. In the case of Barbados, due to data limitations, quarterly GDP was proxied by tourist arrivals. In Barbados, the data available on a yearly basis for tourist arrivals and GDP show that both variables exhibit a high degree of coincidence (including turning points) and association (very high and significant correlation coefficient).

${ }^{14}$ The other countries include Cyprus, Israel, Macao, and Malta. The Caribbean countries include: Barbados, Belize, the Dominican Republic, Grenada, Jamaica, St. Lucia, Trinidad, and Tobago.

${ }^{15}$ Calderón and Fuentes $(2010,2012)$ include only one country from Central America, Costa Rica, which may help to explain that their results seem to be representative mostly of the South American cycle.
} 
Table 3 Data sample for selected studies on business cycles

\begin{tabular}{|c|c|c|c|c|c|c|c|c|c|c|c|}
\hline & Countries & EME & EME & egions & & & & & $\mathrm{DC}$ & Period/periodicity & Variables \\
\hline & & & EAP & ECA & MENA & SSA & $\mathrm{SA}$ & $\mathrm{LAC}$ & & & \\
\hline Current paper & 83 & 44 & 5 & 11 & 3 & 3 & 1 & 21 & 39 & $\begin{array}{l}\text { 1989.1-2012.2 } \\
\text { Quarterly }\end{array}$ & GDP \\
\hline $\begin{array}{l}\text { Titelman, Pérez Caldentey, } \\
\text { and Carvallo (2011) }\end{array}$ & 63 & 37 & 4 & 8 & 2 & 1 & 1 & 20 & 31 & $\begin{array}{l}\text { 1990-2010 } \\
\text { Quarterly }\end{array}$ & $\mathrm{GDP}, \mathrm{C}, \mathrm{I}, \mathrm{X}, \mathrm{M}, \mathrm{G}$ \\
\hline Male (2009) & 35 & 27 & 2 & 4 & 4 & 5 & 3 & 9 & 8 & $\begin{array}{l}\text { 1960.1-2005.4 } \\
\text { Quarterly }\end{array}$ & $\begin{array}{l}\text { Industrial and } \\
\text { agricultural output }\end{array}$ \\
\hline Du Plessis (2006) & 24 & 2 & 1 & $\ldots$ & $\cdots$ & 1 & $\cdots$ & 2 & 22 & $\begin{array}{l}\text { 1970.1-2005.1 } \\
\text { Quarterly }\end{array}$ & $\mathrm{GDP}, \mathrm{C}, \mathrm{I}, \pi, \mathrm{r}, \mathrm{FS}$ \\
\hline Cashin (2004) & 10 & 6 & $\cdots$ & $\ldots$ & $\cdots$ & $\ldots$ & $\cdots$ & 6 & 4 & $\begin{array}{l}1963-2003 \\
\text { Yearly }\end{array}$ & GDP \\
\hline Craigwell and Maurin (2012) & 3 & 3 & $\ldots$ & $\ldots$ & $\ldots$ & $\ldots$ & $\ldots$ & 3 & $\ldots$ & Quarterly & GDP \\
\hline Calderón \& Fuentes (2012) & 65 & 32 & 5 & 9 & 3 & 2 & $\ldots$ & 13 & 34 & $\begin{array}{l}\text { 1970.1-2010.2 } \\
\text { Quarterly }\end{array}$ & GDP \\
\hline Calderón \& Fuentes (2010) & 45 & 19 & 4 & 1 & $\cdots$ & 1 & 1 & 12 & 16 & $\begin{array}{l}\text { 1980.1-2006.2 } \\
\text { Quarterly }\end{array}$ & GDP \\
\hline Rand \& Tarp (2002) & 15 & 14 & 1 & $\cdots$ & 1 & 5 & 2 & 5 & 1 & $\begin{array}{l}\text { 1960.1-1999.4 } \\
\text { Quarterly }\end{array}$ & $\begin{array}{l}\text { Industrial production } \\
\text { Index }\end{array}$ \\
\hline $\begin{array}{l}\text { Pérez Caldentey \& Pineda } \\
\text { (2011) }\end{array}$ & 134 & 104 & 19 & 20 & 13 & 15 & 5 & 32 & 31 & $\begin{array}{l}\text { 1950-2011 } \\
\text { Yearly }\end{array}$ & $\begin{array}{l}\text { GDP, GDP per } \\
\text { capita }\end{array}$ \\
\hline
\end{tabular}

Note: EME = emerging market economies; EAP = East Asia and Pacific; ECA = Europe and Central Asia; MENA = Middle East and North Africa; SSA = Sub-

Saharan Africa; $\mathrm{SA}=$ South Asia; LAC = Latin America and the Caribbean; DC = Developed countries. In our approach, developed countries are high income countries; GDP = Gross Domestic Product; $\mathrm{C}=$ private consumption; $\mathrm{G}=$ government consumption; $\mathrm{I}=$ gross formation of fixed capital; $\mathrm{X}=\mathrm{exports}$; $\mathrm{M}=$ imports; $\pi=$ inflation, $\mathrm{r}=$ nominal rate of interest, $\mathrm{FS}=$ measure of the fiscal stance. The periodicity refers to the most ample data range used in each specific paper.

Source: Authors'own computations 


\section{THE STYLIZED FACTS OF THE EXPANSIONARY AND CONTRACTIONARY PHASES OF THE LATIN AMERICAN AND CARIBBEAN CYCLE}

In comparison to other developed and developing regions of the world, the business cycle of expansions and contractions of Latin America and the Caribbean displays two distinctive features. First, as a general rule, the region has weaker expansions than other developing regions-East Asia and the Pacific, in particular. Second, Latin America and the Caribbean have, on average, contractions in terms of duration and amplitude that tend to converge to those of other countries, both developed and developing. These results are robust in terms of the business cycle methodology used. ${ }^{16}$ Both of these stylized facts are analyzed in detail in the sections that follow.

\subsection{The Expansionary Phase of the Cycle}

The comparative analysis of expansions using the two-cycle methodologies shows that Latin America and the Caribbean have shorter and less intense expansions relative to other regions of the world.

In terms of duration, the classical methodology (using the Bry-Boschan algorithm) shows that Latin America and the Caribbean expansionary periods span, on average, a period of 14 quarters (3.5 years). ${ }^{17}$ With the exception of the Middle East and North Africa (one year), Latin America and the Caribbean's expansion performance is shorter than that of the rest of the regions considered, and in particular than that of East Asia and the Pacific. In the case of East Asia and the Pacific, expansions last nearly eight years, which is almost five years longer than in the case of Latin America and the Caribbean. For the high-income countries, the duration of the expansion is also longer (6 years or roughly two more years than in the case of Latin America and the Caribbean). The deviation cycle methodology corroborates the result that, with the exception of the Middle East and North Africa, Latin America and the Caribbean has one of the shortest expansions among the developing world (Table 4).

\footnotetext{
${ }^{16}$ The results by region refer to medians in order to deal with outliers because the distribution of the observation in terms of amplitude and duration (except perhaps for the duration of the contraction) are skewed.

${ }^{17}$ The Bry-Boschan algorithm to identify turning points was used for both classical and deviation cycle methodologies. These were obtained using MatLab with the help of computer codes provided by Professors John Rand and Finn Tarp (Univesrity of Conpenhagen). Stata was used for the identification of turning points using the Okun and Calculus algorithms and to compute the cycle indicators.
} 
The cycle analysis of the most recent expansion does not alter our conclusions. For the majority of Latin American and the Caribbean, the most recent expansion began in the early 2000s and ended with the Global Financial Crisis (2009). It was one of the longest and most intense expansions in over three decades. However, this expansion episode falls short both in terms of duration and amplitude when compared to the last expansion episode of other regions, and in particular to that of East Asia and the Pacific (26.5 quarters and 29.8 percent for Latin America and the Caribbean and 40 quarters and 53.9 percent for East Asia and the Pacific respectively). ${ }^{18}$

Table 4 Duration and amplitude of the expansionary phase of the cycle for selected regions of the world, 19902012 (quarterly data)

\begin{tabular}{|l|l|l|l||l|}
\hline \multicolumn{5}{|l|}{ Duration (in quarters) } \\
\hline & \multicolumn{2}{|l|}{ Classical Cycle } & Deviation Cycle \\
\hline & Bry-Boschan & Calculus & Okun & Bry-Boschan \\
\hline East Asia and the Pacific & 32.5 & 7.7 & 27.0 & 9.3 \\
\hline Europe and Central Asia & 25.0 & 4.4 & 22.5 & 8.7 \\
\hline Latin America and the Caribbean & 13.6 & 4.4 & 10.8 & 7.5 \\
\hline Middle East and North Africa & 3.5 & 5.4 & 35.5 & 5.8 \\
\hline South Asia & $\ldots$ & 48.0 & $\ldots$ & 8.5 \\
\hline Sub-Saharan Africa & 37.5 & 2.4 & 11.0 & 8.0 \\
\hline High Income & 23.0 & 5.0 & 13.3 & 7.7 \\
\hline \multicolumn{2}{|c|}{ Amplitude (In percentages) } & \\
\hline & Classical Cycle & & \\
\hline & Bry-Boschan & Calculus & Okun & Bry-Boschan \\
\hline East Asia and the Pacific & 39.0 & 11.1 & 29.2 & 5.8 \\
\hline Europe and Central Asia & 43.8 & 10.1 & 39.4 & 9.1 \\
\hline Latin America and the Caribbean & 26.3 & 8.1 & 16.2 & 5.8 \\
\hline Middle East and North Africa & 15.6 & 9.5 & 33.0 & 4.0 \\
\hline South Asia & $\ldots$ & 85.6 & $\ldots$ & 3.2 \\
\hline Sub-Saharan Africa & 40.9 & 9.0 & 12.9 & 3.9 \\
\hline High Income & 26.3 & 6.4 & 14.1 & 4.5 \\
\hline
\end{tabular}

Source: Authors'own computations

Note: ... denotes not available.

\footnotetext{
${ }^{18}$ These numbers refer to the duration and amplitude of a single episode. They refer to the numerator of the duration and amplitude formulas (Equations 3 and 4 above), and in this sense are not strictly comparable to the rest of the cycle indicators provided in the paper. In the case of Europe and Central Asia, the duration and amplitude of the last expansion episode are also greater than those of Latin America and the Caribbean (36.5 quarters and 63.2 percent).
} 
In line with the above results, Latin America and Caribbean also exhibits one of the weakest output gains in the expansionary phase of the cycle. This result holds mostly for the classical cycle methodology in its different turning point algorithms.

The classical cycle (using the Bry-Boschan algorithm) shows that, on average, Latin America and the Caribbean register a 26.3 percent increase in output, respectively. This contrasts with the experience of our benchmark region, East Asia and the Pacific, which records a 39 percent output gain (50 percent above that of Latin America and the Caribbean). In the case of the deviation cycle, Latin America and the Caribbean's amplitude during the expansionary phase is similar to that of East Asia and the Pacific and is below that of Europe and Central Asia.

In any case, the weaker performance of Latin American and Caribbean economies relative to other regions in the expansionary phase of the cycle is underscored when viewed in terms of the cumulative gain in output. Figure 1 shows the gain in cumulative output of East Asia and the Pacific and high-income countries relative to that of Latin America using an average of all criteria used in the paper. ${ }^{19}$ East Asia and the Pacific have a gain in output that is, almost thrice that of Latin America and the Caribbean. For its part, the gain in output of the high-income economies grouping is 10 percent higher relative to that of Latin America and the Caribbean (Figure 1).

\footnotetext{
${ }^{19}$ Using only the deviation cycle methodology the cumulative gain in output is also larger for East Asia and the Pacific in relation to Latin America and the Caribbean.
} 
Figure 1 Average cumulative output gain of East Asia and the Pacific and the high-income country grouping relative to Latin America and the Caribbean (1990-2012)

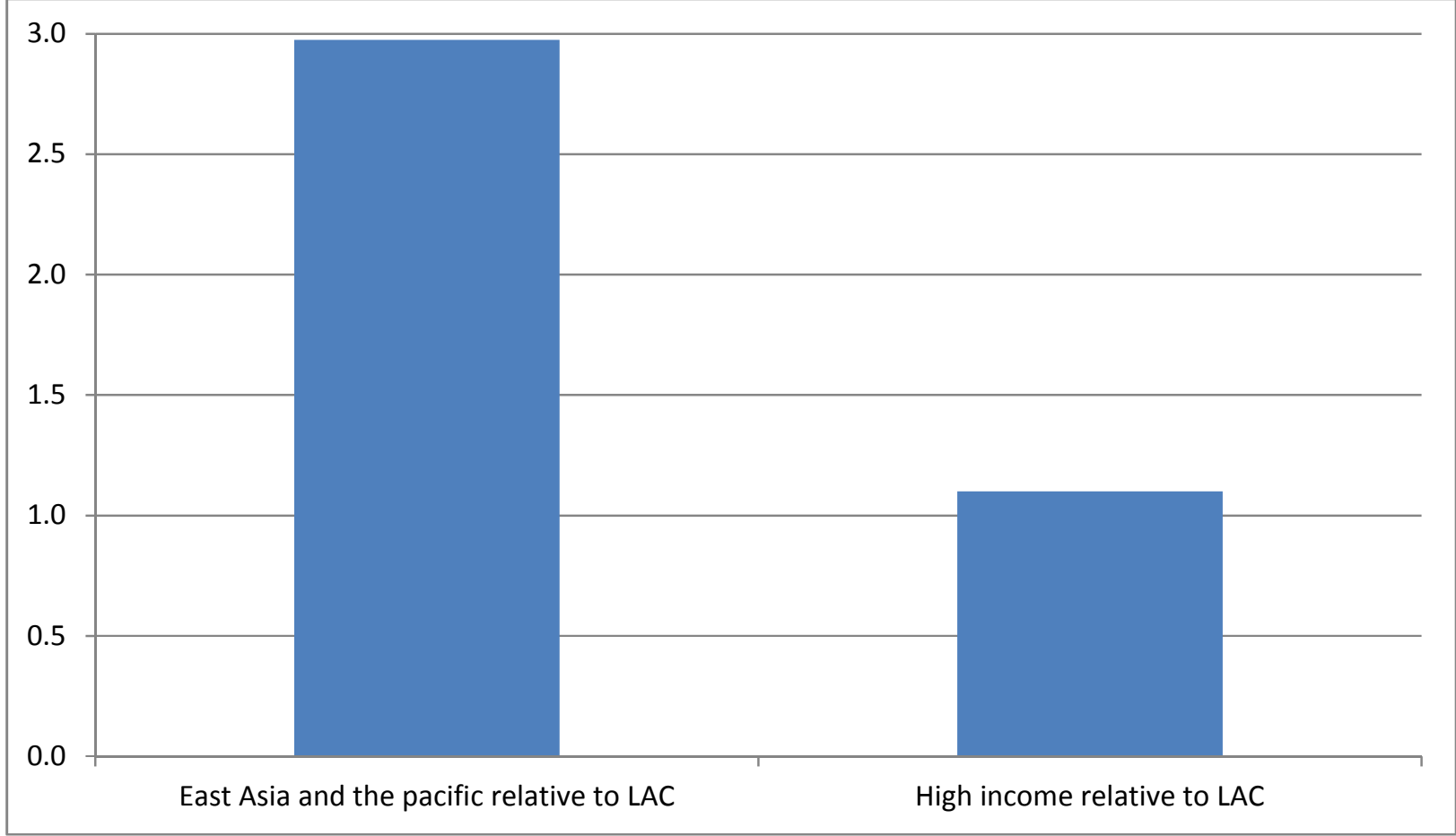

Note: Refers to the average of the Bry-Boschan, Calculus, Okun and cycle deviation for the period 1990-2012.The cumulative output gain is computed as the product of the amplitude and duration of the expansion phase of East Asia and high-income economies relative to that of Latin America and the Caribbean.

Source: Authors'own computations

The application of our approach separately to South America, Central America, and Mexico does not change the results found at the regional level. The duration of the expansion for South America, Central America, and Mexico is 15, 25, and 23, quarters respectively. The amplitude of their expansion reaches 28 percent, 27 percent, and 26 percent, respectively (Table $5)$. 
Table 5 Duration and amplitude of the expansionary phase of the cycle for Latin America and the Caribbean and its sub-regions 1990-2012

\begin{tabular}{|c|c|c|c|c|}
\hline \multicolumn{5}{|c|}{ Duration (In quarters) } \\
\hline & \multicolumn{3}{|c|}{ Classical Cycle } & Deviation Cycle \\
\hline & Bry-Boschan & Calculus & Okun & Bry-Boschan \\
\hline Latin America and the Caribbean & 13.6 & 4.4 & 10.8 & 7.5 \\
\hline South America & 15.3 & 4.8 & 13.1 & 7.8 \\
\hline Central America & 25.0 & 4.5 & 27.0 & 7.5 \\
\hline Mexico & 23.0 & 5.1 & 11.0 & 11.3 \\
\hline \multicolumn{5}{|c|}{ Amplitude (In percentages) } \\
\hline & \multicolumn{3}{|c|}{ Classical Cycle } & Deviation Cycle \\
\hline & Bry-Boschan & Calculus & Okun & Bry-Boschan \\
\hline Latin America and the Caribbean & 26.3 & 8.1 & 16.2 & 5.8 \\
\hline South America & 27.9 & 7.8 & 14.7 & 5.8 \\
\hline Central America & 27.0 & 8.4 & 29.2 & 4.9 \\
\hline Mexico & 25.6 & 6.9 & 15.3 & 6.2 \\
\hline
\end{tabular}

Source: Authors'own computations.

Further corroborating evidence regarding the limited nature of the expansion in Latin America is provided by the disaggregation of this phase of the cycle into its two sub-phases, acceleration and deceleration. Acceleration is defined by a GDP growing at an increasing rate, or, in other words, by a first and second positive derivative of the GDP level series. Deceleration refers to a GDP growing at decreasing rates, or, in other words, the first derivative of the GDP series in levels is positive, while the second derivative is negative.

As shown in Figure 2, Latin America and the Caribbean have one the weakest rates of growth for both the acceleration and deceleration sub-phases in comparison to other developing and developed regions. The average rate of growth in the acceleration phase reaches 6.1 percent for Latin America and the Caribbean, while for other regions such as East Asia and the Pacific, it reaches roughly 7 percent. In a similar way, Latin America also experiences a slower deceleration phase than other regions, with the exception of Middle East and North Africa and Sub-Saharan Africa. 
Figure 2 Average rate of growth of GDP during the acceleration and deceleration sub-phases of the cycle for selected developing regions of the world, 1990-2012

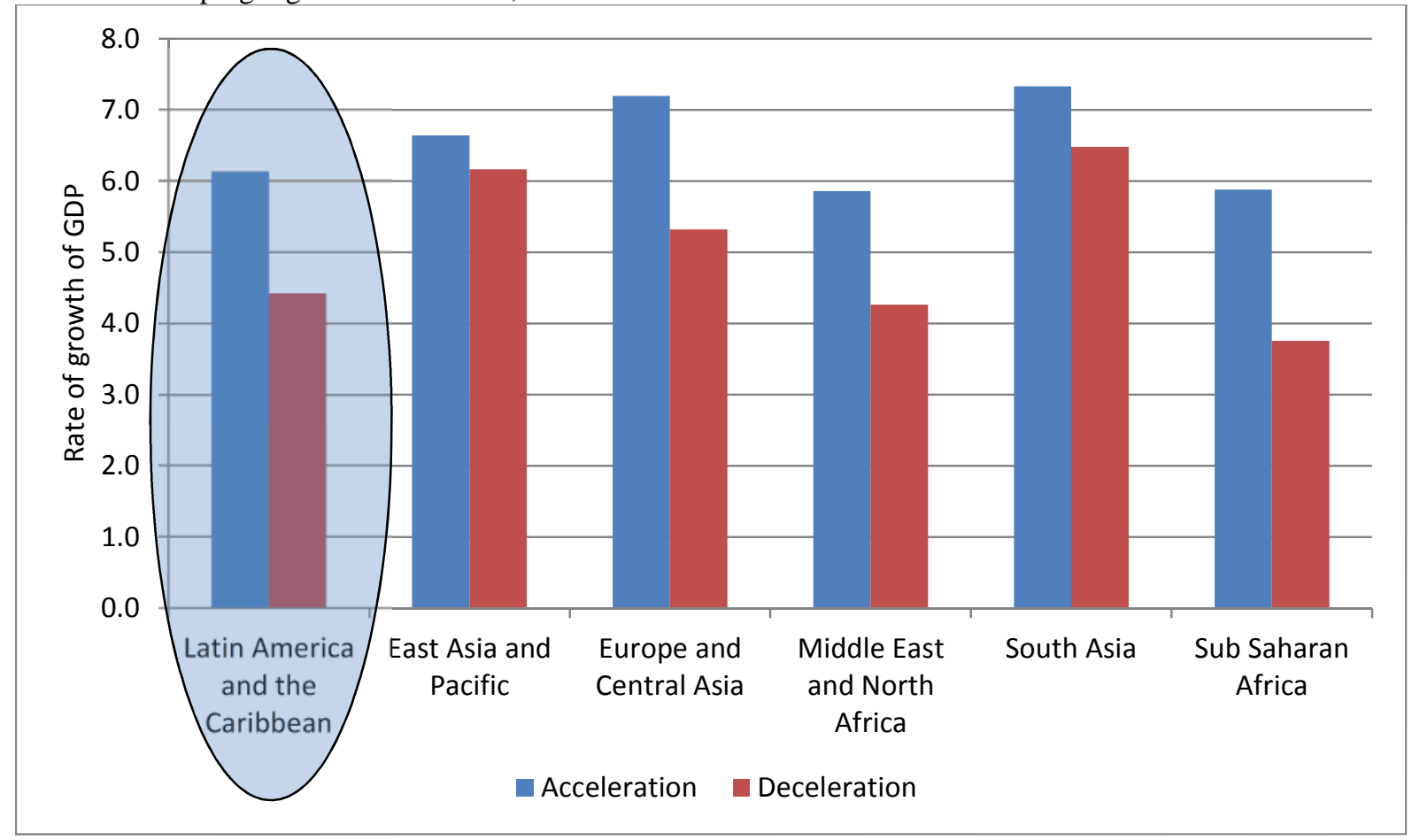

Source: Authors'own computations

\subsection{The Contraction Phase of the Economic Cycle}

In contrast to the results obtained for the expansions, the duration and intensity of the contraction for Latin American and Caribbean countries tends to conform to those found for other regions as measured by both the classical and deviation cycle methodologies.

In the case of the classical cycle methodology, the Bry-Boschan algorithm estimates that, with the exception of the Middle East and North Africa, the duration of contractions is less than a year. These range between 2.7 to 3.8 quarters (that is, between 8 and 11 months). The duration of contractions for Latin America and the Caribbean, Europe and Central Asia, and East Asia and the Pacific are very similar, between 3.3 and 3.8 quarters, or between 10 to 11 months.

The Okun and Calculus criterion yield a higher degree of uniformity in the duration of contractions among developing regions, and according to both, the experience of Latin America and the Caribbean also conforms to the results found for other developing regions (Table 6). 
Table 6 Duration and amplitude of the contractionary phase of the cycle for selected regions of the world, 19902012 (quarterly data)

\begin{tabular}{|c|c|c|c|c|}
\hline & \multicolumn{4}{|c|}{ Duration (In quarters) } \\
\hline & \multicolumn{3}{|c|}{ Classical Cycle } & \multirow{2}{*}{$\begin{array}{l}\text { Deviation Cycle } \\
\text { Bry-Boschan }\end{array}$} \\
\hline & Bry-Boschan & Calculus & Okun & \\
\hline East Asia and the Pacific & 3.3 & 1.6 & 2.2 & 4.8 \\
\hline Europe and Central Asia & 3.8 & 1.6 & 3.3 & 5.3 \\
\hline Latin America and the Caribbean & 3.8 & 1.6 & 3.3 & 6.0 \\
\hline Middle East and North Africa & 7.3 & 1.2 & 2.8 & 6.5 \\
\hline South Asia & $\ldots$ & 1.0 & $\ldots$ & 6.7 \\
\hline Sub-Saharan Africa & 2.7 & 1.3 & 2.5 & 5.3 \\
\hline \multirow[t]{4}{*}{ High Income } & 4.0 & 1.6 & 3.4 & 6.3 \\
\hline & \multicolumn{4}{|c|}{ Amplitude (In percentages) } \\
\hline & \multicolumn{3}{|c|}{ Classical Cycle } & Deviation Cycle \\
\hline & Bry-Boschan & Calculus & Okun & Bry-Boschan \\
\hline East Asia and the Pacific & -10.6 & -3.7 & -4.4 & -5.8 \\
\hline Europe and Central Asia & -11.6 & -4.6 & -7.1 & -9.6 \\
\hline Latin America and the Caribbean & -4.6 & -2.1 & -3.2 & -6.2 \\
\hline Middle East and North Africa & -7.0 & -1.2 & 0.3 & -3.8 \\
\hline South Asia & $\ldots$ & -0.2 & $\ldots$ & -2.9 \\
\hline Sub-Saharan Africa & -7.1 & -1.7 & -1.4 & -3.8 \\
\hline High Income & -4.9 & -1.8 & -2.6 & -4.3 \\
\hline
\end{tabular}

Note: ... denotes not available.

Source: Authors'own computations

The application of the deviation cycle methodology corroborates the above findings. Contractions tend to last for a similar length of time and the Latin America and the Caribbean region is not an exception to this rule. ${ }^{20}$

Moreover, as explained earlier, due to the fact that the deviation cycle approach sees the cycle as a stationary process, whereby the deviations from trend cancel each other out over time, it does not capture the asymmetry of the cycle. Indeed, as shown in Figure 3 below, the duration of the expansion relative to that of the contraction is very similar for all regions, nearing a value of one (i.e., the expansions last as long as the contractions). This contrasts with the classical cycle methodology where the contraction and the expansion are independent events. The standard deviation for the duration of the contraction using the classical cycle methodology equals 2.64, while for the deviation from trend, it is equal to 0.34 (see Figure 3 below).

\footnotetext{
${ }^{20}$ However, this methodology, as explained in Section 1.1, tends to produce longer contractions across all regions than the classical cycle methodology (see Pagan 2003 on this point). Indeed, contractions according to this methodology tend to last for at least five quarters in most cases.
} 
Figure 3 Asymmetry of the duration of the cycle based on the deviation from trend and classical cycle analysis, selected regions of the world (1990-2012, averages based on quarterly data)

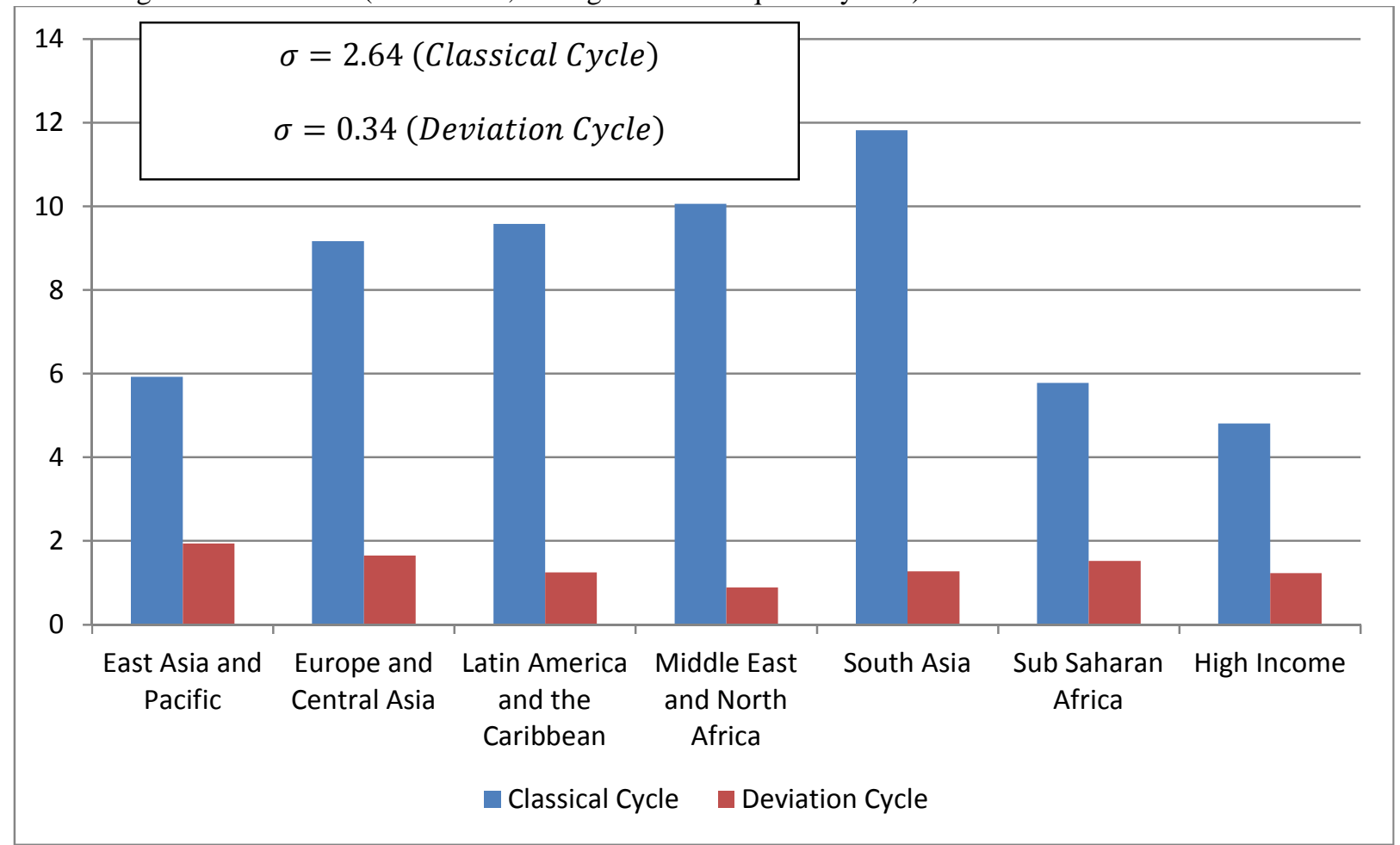

Source: Authors'own computations

In line with these results, contractions do not prove to be more intense in the case of Latin America and the Caribbean in relation to other regions. As shown in Table 6 above, according to the Bry-Boschan algorithm used in the classical cycle approach, Latin America and the Caribbean have the smallest amplitude of contractions among all developing and developed regions. The average amplitude of the contractions equals 4.6 percent for Latin America and the Caribbean. This nears that of the high-income country grouping (4.9 percent) and falls below that of East Asian and Pacific (10.6 percent), Europe and Central Asia (11.6 percent), Middle East and North Africa (7.0 percent), and Sub-Saharan Africa (7.1 percent).

According to the two other criteria (Calculus and Okun), the amplitude of the contraction in Latin America and the Caribbean is below that of East Asia and the Pacific, and Europe and Central Asia.

The findings of the deviation cycle approach are not as clear cut. The intensity of the contraction for Latin America and the Caribbean is below that of Europe and Central Asia, similar to that of East Asia and the Pacific, and surpasses that of the rest of the regions. 
A more detailed analysis for Latin America by sub-regions (South America, Central America, Caribbean), indicates that the dispersion of the amplitude in the case of a contraction is higher than that of an expansion. South America and Mexico seem to have more pronounced and sharp contractions relative to Central America and the Caribbean. In the cases of South America and Mexico, the amplitude is equal to 7.1 percent and 7.9 percent using the BryBoschan criterion, and 2.4 percent and 2.6 percent using the Calculus criterion. For their part, the respective amplitudes for Central America and the Caribbean using both criteria are 3.8 percent, 5.4 percent, and 1.3 percent and 3.1 percent, respectively (Table 7$){ }^{21}$

Table 7 Amplitude of the contractionary phase of the cycle for Latin America and the Caribbean and its subregions, 1990-2012 (in percentages using quarterly data)

\begin{tabular}{|l|l|l|}
\hline & Bry-Boschan & Calculus \\
\hline Latin America and the Caribbean & -4.6 & -2.1 \\
\hline South America & -7.1 & -2.4 \\
\hline Central America & -3.8 & -1.2 \\
\hline México & -7.9 & -2.6 \\
\hline Caribbean & -5.4 & -3.1 \\
\hline
\end{tabular}

Source: Authors'own computations

This difference at the sub-regional level is explained by the fact that the strongest and most intense crises in the period under study — the Mexican crisis (1994-1995), the Asian crisis (1997-1998), the Russian crisis (1998) and the Argentine crisis (2001-2002) - had their epicenter in Mexico or South America.

\section{THE COMPLETE LATIN AMERICAN AND CARIBBEAN CYCLE OF EXPANSIONS AND CONTRACTIONS}

Both of the stylized facts analyses above (weaker expansions and convergent contractions) imply that the complete Latin America and the Caribbean cycle exhibits, for the most part, the shortest duration and smallest amplitude in relation to other regions.

The length of the duration of an entire cycle using the classical cycle methodology (and, as a reference, the Bry-Boschan criterion) is roughly 17 quarters for Latin America and the Caribbean. This is below that found for high-income countries (27 quarters) and also for the majority of developing regions. In the particular case of East Asia and the Pacific, our

${ }^{21}$ The Caribbean includes the Dominican Republic. 
benchmark, the cycle lasts 36 quarters, that is, almost five years longer than that of Latin America and the Caribbean (Table 8).

These results do not change in any significant manner when the comparison is undertaken using the deviation cycle analysis. This shows that with the exception of the Middle East and North Africa, Latin America and the Caribbean has the shortest cycle of all the regions included in the exercise. ${ }^{22}$

Table 8 Duration (in quarters) of the complete cycle on a regional basis, 1990-2012 (quarterly data)

\begin{tabular}{|l|l|l|l|l|}
\hline Region & \multicolumn{2}{l|}{ Classical Cycle } & Deviation Cycle \\
\hline & Bry-Boschan & Calculus & Okun & Bry-Boschan \\
\hline East Asia and the Pacific & 35.8 & 9.3 & 29.2 & 14.0 \\
\hline Europe and Central Asia & 28.8 & 6.1 & 25.8 & 13.9 \\
\hline Latin America and the Caribbean & $\mathbf{1 7 . 4}$ & $\mathbf{6 . 0}$ & $\mathbf{1 4 . 1}$ & $\mathbf{1 3 . 5}$ \\
\hline Middle East and North Africa & 10.8 & 6.5 & 38.3 & 12.3 \\
\hline South Asia & $\ldots$ & 49.0 & $\ldots$ & 15.2 \\
\hline Sub-Saharan Africa & 40.2 & 3.7 & 13.5 & 13.3 \\
\hline High Income & 27.0 & 6.6 & 16.7 & 14.0 \\
\hline
\end{tabular}

Note: ... denotes not available.

Source: Authors'own computations

At the same time that Latin America exhibits the shortest duration of cycles, it also displays, using the smallest amplitude, the shortest distance between the intensity of the contraction and that of the expansion according the classical cycle methodology. Taking East Asia and the Pacific as a reference point, the amplitude of its cycle is 60 percent greater than that of Latin American and the Caribbean (Table 9).

\footnotetext{
${ }^{22}$ Throughout the paper, the deviation cycles are computed using the Hodrick-Prescott filter. Some authors suggest that the difference in duration, especially between developed and developing economies, is due to a lack of homogeneity in the data, and in particular of using industrial activity indices for developing countries and GDP data for developed countries. See Male (2009) and Du Plessis (2006). Our results are not affected by the use of GDP or of an index of industrial production. Using the latter measure, Latin America and the Caribbean still exhibits the shortest full cycle duration.
} 
Table 9 Amplitude of the complete cycle on a regional basis, 1990-2012 (in percentage using quarterly data)

\begin{tabular}{|l|l|l|l|l|}
\hline \multicolumn{2}{|l|}{ Classical Cycle } & \multicolumn{2}{l|}{ Deviation Cycle } \\
\hline Region & Bry-Boschan & Calculus & Okun & Bry-Boschan \\
\hline East Asia and the Pacific & 49.6 & 14.8 & 33.5 & 11.6 \\
\hline Europe and Central Asia & 55.4 & 14.7 & 46.6 & 18.7 \\
\hline Latin America and the Caribbean & $\mathbf{3 0 . 9}$ & $\mathbf{1 0 . 3}$ & $\mathbf{1 9 . 3}$ & $\mathbf{1 2 . 0}$ \\
\hline Middle East and North Africa & 22.5 & 10.6 & 32.7 & 7.7 \\
\hline South Asia & $\ldots$ & 85.8 & $\ldots$ & 6.1 \\
\hline Sub-Saharan Africa & 48.0 & 10.6 & 14.3 & 7.7 \\
\hline High Income & 31.1 & 8.2 & 16.7 & 8.8 \\
\hline
\end{tabular}

Note: ... denotes not available.

Source: Authors'own computations

\section{CYCLES AND LONG-RUN OUTCOMES: CONCEPTUAL ISSUES AND SOME PRELIMINARY EVIDENCE}

The specific characteristics of the cycle for Latin America and Caribbean countries and, in particular, the weak nature of expansions are not confined to short-run analysis. They are also reflected in the behavior of variables such as productivity and investment, which have an impact on long-run growth trajectories. In this sense, we follow the more recent literature that establishes a connection between cyclical fluctuations and long-term outcomes (Dickens and Madrick 2010; Dutt and Ros 2009; Aghion, Hemous, and Kharroubi 2010; IMF 2009; European Commission 2009). ${ }^{23}$

Table 10 shows the duration and amplitude of the expansion for labor productivity for Latin America and the Caribbean countries in comparison to the rest of the countries included in our sample. Independently of the cycle methodology used, and in line with our previous results, Latin America and the Caribbean have, for the most part, one of the shortest expansions in productivity growth.

\footnotetext{
${ }^{23}$ Part of this literature sustains that shocks such as wars, natural disasters, financial crisis, and, in general contractions, in economic activity can lead to income per capita divergence by causing permanent losses in trend output and lower long-run growth. The specificities and transmission mechanisms include, among others, the effect of aggregate demand fluctuactions on the capital stock, investment, and labor (e.g, Dutt and Ros 2009, IMF 2009), financing constraints (Aghion, Hemous, and Kharroubi 2010), or the impact on total factor producticity or the permanent destruction of human capital (European Comission 2009). Another transmission mechanism is volatility (Ramey and Ramey 1995; Turnovsky and Chattopadhyay 1998; Yigit 2003).
} 
Table 10 Duration and amplitude of the expansionary phase of the labor productivity cycle for selected regions of the world using the classical cycle methodology, 1990-2012 (yearly data)

\begin{tabular}{|l|l|l|}
\hline & \multicolumn{2}{|c|}{ Duration (In years) } \\
\hline & Bry-Boschan & Calculus \\
\hline East Asia and the Pacific & 4.3 & 4.3 \\
\hline Europe and Central Asia & 5.5 & 5.5 \\
\hline Latin America and the Caribbean & 3.8 & 3.8 \\
\hline Middle East and North Africa & 3.3 & 3.3 \\
\hline South Asia & 4.8 & 4.7 \\
\hline Sub-Saharan Africa & 2.6 & 2.6 \\
\hline High Income & 6.3 & 6.3 \\
\hline & \multicolumn{2}{|c|}{ Amplitude (In percentages) } \\
\hline & Bry-Boschan & Calculus \\
\hline East Asia and the Pacific & 23.4 & 23.4 \\
\hline Europe and Central Asia & 33.7 & 33.7 \\
\hline Latin America and the Caribbean & 13.6 & 13.6 \\
\hline Middle East and North Africa & 17.2 & 17.2 \\
\hline South Asia & 16.0 & 15.2 \\
\hline Sub-Saharan Africa & 8.5 & 8.5 \\
\hline High Income & 17.7 & 17.6 \\
\hline
\end{tabular}

Note: Labor productivity refers to labor productivity per person employed in 2011 US\$ (converted to 2011 price level with updated 2005 EKS PPPs).

Source: Authors'own computations

In this regard, the differences between the cumulative gain (the product of the amplitude and the duration) in productivity between Latin America and the Caribbean and East Asia and the Pacific are worth highlighting. The cumulative gain in labor productivity during the expansionary phase of the cycle is 25 percent for Latin America and the Caribbean and twice this figure (50 percent) in the case of East Asia and the Pacific.

Jointly with the fact that Latin America and the Caribbean experience weaker expansions than other regions and, in particular, than East Asia and the Pacific, this type of evidence may help to explain the reason why the countries of East Asia and the Pacific have been able to sustain over time a high GDP growth path relative to the case of Latin America and the Caribbean. This is shown in Figure 4, which plots the trend of GDP for the period 19602010 for both regions.

Whereas the East Asia and Pacific region has been able to maintain a rising trajectory throughout the period, Latin America and the Caribbean experience a structural break in the 1980s, due most likely to the effects of the debt crisis, from which the region has not been able 
to recover in the following two decades. At a more detailed level of analysis, the figure shows that the GDP trend between 1960 and the early 1980s (period I) of Latin America and the Caribbean is similar to that in East Asia and the Pacific. Then, starting with the lost decade of the 1980s, it tends to decline and does not recover in the 1990s or the first decade of the 2000s, meaning that in this sub-period growth rates are lower than before the debt crisis (period II).

Figure 4 GDP trend for Latin America and the Caribbean and East Asia and the Pacific, 1960-2010 (logarithmic scale, annual data)

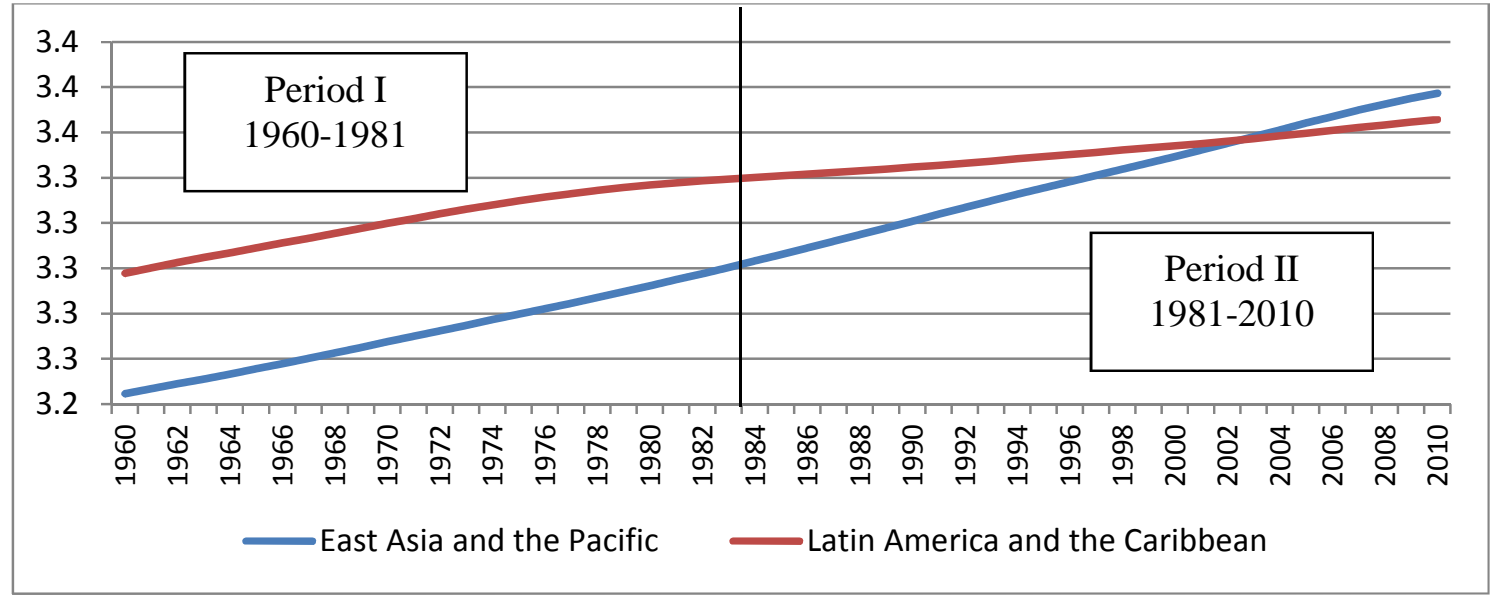

Note: The computations were undertaken using the deviation cycle methodology.

Source: Economic Commission for Latin America and the Caribbean (ECLAC), on the basis of World Bank, "World Development Indicators" and "Global Finance" [online] http://www.gfmag.com/.

The long-term effects of the crisis are seen in the structural break in the region's GDP trend. At the same time, the weak nature of recoveries is underscored by the fact that the economic policies implemented in the two decades after the crisis did not reverse those effects. Even in the period of fastest growth witnessed by Latin America and the Caribbean over the past 30 years (2003-2008), the countries of the region, with few exceptions, did not succeed in reversing the structural break or improving the trend. This is unlike what happened in Asia: the 1997 crisis, one of the severest to hit the countries of East Asia, did not change the path of trend GDP.

An additional piece of evidence linking the fluctuations of the cycle to long-run growth is provided by the behavior of public investment, which is also clearly asymmetric, with drops during recessions being much sharper than increases during upswings. As shown in Table 11 
considering data for six countries in the region, public investment in infrastructure fell by an average of 36 percent in the downswing of the business cycle. ${ }^{24}$

Declines in public infrastructure investment tend to be sharper than any increase during the recovery phase. In the sectors considered, the contraction is, on average, 40 percent greater than the subsequent expansion. In the power and telecommunications sectors, the difference between the decline in investment during a contraction and the increase during the expansion is even greater (35 percent increase and -52 percent decline for the energy sector and 28 percent and -58 percent for the telecommunications sector, respectively). Such a pattern has negative impacts on capital accumulation over time.

Table 11 Latin America (selected countries): duration and amplitude of expansions and contractions of the cycle of public investment in infrastructure, 1980-2010 (yearly data)

\begin{tabular}{|c|c|c|c|c|}
\hline & \multicolumn{2}{|c|}{ Expansion } & \multicolumn{2}{|c|}{ Contraction } \\
\hline & Duration & Amplitude & Duration & Amplitude \\
\hline Total & 2.7 & 25.6 & 2.2 & -35.6 \\
\hline Energy sector & 1.9 & 34.7 & 2.0 & -51.5 \\
\hline Roads and railways & 2.1 & 32.3 & 1.7 & -33.1 \\
\hline Telecommunications & 1.8 & 28.1 & 1.9 & -58.0 \\
\hline Water and sanitation & 1.6 & 24.2 & 1.7 & -23.8 \\
\hline
\end{tabular}

Note: The Bry-Boschan algorithm was used for identifying the turning points.

Source: ECLAC 2012

The contraction in investment can have short-run effects on aggregate demand, but it also has an impact on the long-run trajectory of the economy. This is due not only to the fact that public investment contributes to the growth of the economy, but also to the fact that investment in decisions, in general, are often irreversible ("once installed, capital has little or no value unless used in production") and this characteristic provides a link between the decisions taken in the short run with medium- and long-run outcomes.

Irreversibility can often become an important factor in the decision not to invest in the downward phase of the cycle due, for example, to the growing risks associated with the current and future macroeconomic context. In this sense, a downward phase of the business cycle can be associated with a low capital accumulation, which, in turn, results in furthering the decline in investment, undermining not only the job creating capacity of the economy, but also its recovery potential.

24 Argentina, Brazil, Chile, Colombia, Mexico, and Peru, which account for 85.5 percent of the region's GDP between them. 


\section{CONCLUSION: WHERE WE ARE AND THOUGHTS FOR FURTHER RESEARCH}

This paper shows that independently of the methodology adopted, the Latin American and Caribbean cycle exhibits two distinctive features. The first and most important one is that Latin America and the Caribbean register weaker expansions than those of other regions and, in particular, than those of the East Asian and Pacific region. The most recent expansion (20032007), which is by far one of the most intense in the history of the region, does not alter this conclusion in the sense that during period, Latin America and the Caribbean's rate of growth remained below that of other developing regions. A second distinctive feature is that Latin America and the Caribbean's contractions conform in terms of duration and amplitude to those of the rest of the world.

Weaker expansions and convergent contractions imply, as a result, that the complete cycle of expansions and contractions tends to be shorter and with a smaller amplitude for Latin America and the Caribbean relative to other regions of the world.

Traditionally, cycle patterns are viewed as short-run demand-led phenomena with no bearing on growth trends. However, this paper argues that the specificities of the cycle are not only relevant to the short-run. They are also reflected in the behavior of variables such as productivity and investment, which are linked to long-run growth performance.

In the particular case of Latin America and the Caribbean, the behavior of both productivity and investment reflect the weak nature of the region's expansions. In fact, the study of the particularities of the cycle, including weak expansions in output and productivity, may be central to explain, at least in part, the reason why the region has not been able to sustain growth concomitantly to other regions and, in particular, to East Asia and the Pacific.

The findings presented in this paper open important avenues to explore further and analyze the short- and long-term performance of Latin America and Caribbean economies.

First, cycle analysis should increase its focus on the nature and behavior of expansions. Sustaining evidence is provided by the fact that contractions tend to be somewhat homogeneous across regions in terms of duration and amplitude. However, this is not the case with expansions. Expansions are heterogeneous in terms of duration and amplitude. Improving our understanding of the differences in the expansionary dynamics of countries and regions can further our understanding of the differences in their rates of growth and levels of development, including those of Latin America and the Caribbean. 
Second, as it is well established, the management of the cycle affects the short-run fluctuations of economic activity and, hence, volatility. But additionally, it is not trend-neutral. Hence, the effects of aggregate demand management policies may be more persistent over time and less transitory than currently thought to be. This provides a justification to reconsider the usefulness of stabilization policies and their effects, from a short- and long-run view, including their potential trade-offs, and to re-think how to articulate and coordinate what are currently called demand-side with supply-side policies. 


\section{REFERENCES}

Aghion, P., D. Hemous, and E. Kharroubi. 2010. "Cyclical Fiscal Policy, Credit Constraints, and Industry Growth.” BIS Working Paper No. 340. Basel, Switzerland: Bank for International Settlements.

Artis, M., M. Maecrellin, and T. Proietti. 2003. "Dating the Europe Area Business Cycle." Working Paper 2002/24. Florence, Italy: European University Institute. http://www.eui.eu/Personal/Marcellino/23.pdf

Blanchard, O. and S. Fischer. 1989. Lectures of Macroeconomics. Cambridge, MA: MIT Press.

Bry, G. and C. Boschan. 1971. Cyclical Analysis of Time Series: Selected Procedures and Computer Programs. New York, NY: National Bureau of Economic Research.

Burns, A. E. and W. C. Mitchell. 1946. Measuring Business Cycles. New York, NY: National Bureau of Economic Research.

Calderón, C. and J. R. Fuentes. 2010. "Characterizing the Business Cycles of Emerging Economies." Working Paper No. 371. Santiago, Chile: Pontifical Catholic University of Chile, Institute of Economics. http://www.webmeets.com/files/papers/LACEALAMES/2012/495/Calderon\%20Fuentes \%20Cycles\%20\%2819\%20March\%202012\%29.pdf

— 2012. "Have Business Cycles Changed over the Last Two Decades? An Empirical Investigation." http://www.webmeets.com/files/papers/LACEA-

LAMES/2012/495/Calderon\%20Fuentes\%20Cycles\%20\%2819\%20March\%202012\%29 .pdf

Cashin, P. 2004. "Caribbean Business Cycles.” IMF Working Paper. WP/04/136. Washington, DC: International Monetary Fund.

Craigwell, R. and A. Maurin. 2012. "An Analysis of Economic Cycles of the English Speaking Caribbean Countries." Mimeo. http://www.cbvs.sr/CCMF/ccmf_papers/Economic\%20cycles\%20of\%20the\%20English \%20speaking\%20Caribbean_Craigwell\%20\&\%20Wright.pdf

Dickens, W. T. and J. G. Madrick. 2010. "Long-term Consequences of Economic Fluctuations." Mimeo. New York, NY: Schwartz Center for Economic Policy Analysis.

Du Plessis, S. 2006. "Business Cycles in Emerging Market Economies: A New View of the Stylized Facts." Stellenbosch Economic Working Papers 2/ 2006. Stellenbosch, South Africa: University of Stellenbosch.

Dutt, A. K. and J. Ros. 2009. "Long-run Effects of Aggregate Demand Fluctuations." Preliminary draft. Prepared for a Schwartz Center for Economic Policy Analysis conference on "The Long Term Impacts of Short Term Fluctuations: Theory, Evidence and Policy." Brookings Institution, November 5-6.

ECLAC. 2002. Globalization and Development. Santiago, Chile: ECLAC. 
—. 2012. Structural Change for Equality. Santiago, Chile: ECLAC.

European Commission. 2009. "Impact of the Current Economic and Financial Crisis on Potential Output." Occasional Papers No. 49. Directorate-General for Economic and Financial Affairs. Brussels, Belgium: European Commission. http://ec.europa.eu/economy_finance/publications

Frisch, R. 1933. "Propagation Problems and Impulse Problems in Dynamic Economics." In Economic Essays in Honour of Gustav Cassel. London: George Allen and Unwin, Ltd., 171-205.

Harding, D. and A. Pagan. 2002a. "A Comparison of Two Business Cycle Dating Methods." Journal of Economic Dynamics and Control 27(9): 1681-1690.

- 2002b. "Dissecting the Cycle: A Methodological Investigation." Journal of Monetary Economics 49(2): 365-381.

_. 2002c. "Rejoinder to James Hamilton." Journal of Economic Dynamics and Control 27(9): $1695-1698$.

- 2005. "A Suggested Framework for Classifying the Modes of Cycle Research." Journal of Applied Econometrics 20(2): 151-159.

IMF. 2009. World Economic Outlook. Washington DC: International Monetary Fund.

Kydland, F. E. and E. C. Prescott. 1990. "Business Cycles: Real Facts and a Monetary Myth." Federal Reserve Bank of Minnesota Quarterly Review Spring: 383-398.

Lucas, R. 1987. Models of Business Cycles. Oxford, UK: Basil Blackwell.

Male, R. L. 2009. "Developing Country Business Cycles: Characterizing the Cycle and Investigating the Output Persistence Problem.” PhD Thesis. York, England: University of York. Department of Economics and Related Studies.

Medio, A. 2008. “Trade Cycle.” In S. N. Durlauf and L. E. Blume (Eds.), The New Palgrave Dictionary of Economics. Second Edition. New York, NY: Palgrave Macmillan.

Pagan, A. 2003. "Three Views of the Business Cycles and their Implications." Mimeo. Lecture given at Southern Methodist University, Dallas, TX,

Pérez Caldentey, E. and R. Pineda. 2011. "Does Latin America Lag Behind Due to Sharper Recessions and/or Slower Recoveries?" MPRA Working Paper 25036. Munich, Germany: Munich Personal RePEc Archive. http://mpra.ub.uni-muenchen.de/25036/

Ramey, G. and V. A. Ramey. 1995. "Cross-Country Evidence on the Link between Volatility and Growth." American Economic Review, American Economic Association 85(5): $1138-51$.

Rand, J. and F. Tarp. 2002. "Business Cycles in Developing Countries: Are They Different?" World Development 30(12): 2071-2088.

Sargent, T. J. 1987. Macroeconomic Theory. Second Edition. Boston, MA: Academic Press. 
Titelman, D., E. Pérez Caldentey, and P. Carvallo. 2011. "The Stylized Facts of the Latin American and Caribbean Business Cycle." Mimeo. Economic Commission for Latin America and the Caribbean (ECLAC).

Titelman, D., E. Pérez-Caldentey, and R. Minzer. 2008. "Una Comparación de la Dinámica e Impactos de los Choques de Términos de Intercambio y Financieros en América Latina 1980-2006." Serie Financiamiento del Desarrollo. Santiago, Chile: Economic Commission for Latin America and the Caribbean (ECLAC).

Turnovsky S. and P. Chattopadhyay. 1998. "Volatility and Growth in Developing Economies: Some Numerical Results and Empirical Evidence." Discussion Papers in Economics No. 0055. Seattle, WA: University of Washington.

World Bank. 2013. World Development Indicators and Global Finance. Washington, DC: World Bank. http://databank.worldbank.org/ddp/home.do

Yigit, F. P. 2003. "Re-evaluating the Link between Volatility and Growth." Electronic Theses, Treatises and Dissertations. Paper 664. Tallahassee, FL: The Florida State University DigiNole Commons.

Zambelli, S. 2007. “A Rocking Horse That Never Rocked: Frisch's 'Propagation Problems and Impulse Problems." ' History of Political Economy 39(1): 145-166.

Zarnowitz, V. 1992. "Macroeconomics and Business Cycles: An Overview." NBER Chapters. In Business Cycles: Theory, History, Indicators, and Forecasting. Chicago, IL: University of Chicago Press. National Bureau of Economic Research. 
APPENDIX: LIST OF COUNTRIES INCLUDED AND RESPECTIVE TIME DOMAIN FOR GDP

\begin{tabular}{|c|c|c|}
\hline & First observation & Last observation \\
\hline \multicolumn{3}{|c|}{ East Asia and Pacific } \\
\hline China & 1993:Q1 & 2012:Q1 \\
\hline Indonesia & 1997:Q1 & 2012:Q2 \\
\hline Malaysia & 1989:Q1 & 2012:Q1 \\
\hline Filipinas & 1989:Q1 & 2011:Q4 \\
\hline Thailand & 1993:Q1 & 2012:Q1 \\
\hline \multicolumn{3}{|c|}{ Europe and Central Asia } \\
\hline Bulgaria & 2002:Q1 & 2011:Q4 \\
\hline Belorussia & 1992:Q1 & 2012:Q1 \\
\hline Georgia & 1996:Q1 & 2011:Q4 \\
\hline Kyrgyzstan & 2000:Q1 & 2012:Q1 \\
\hline Latvia & 1990:Q1 & 2012:Q1 \\
\hline Lithuania & 1993:Q1 & 2012:Q1 \\
\hline Rumania & 1998:Q1 & 2012:Q1 \\
\hline Russia & 1995:Q1 & 2012:Q1 \\
\hline Turkey & 1989:Q1 & 2012:Q1 \\
\hline Ukraine & 2001:Q1 & 2012:Q1 \\
\hline Macedonia, FYR & 2004:Q1 & 2012:Q1 \\
\hline \multicolumn{3}{|c|}{ Latin America and the Caribbean } \\
\hline Argentina & 1990:Q1 & 2012:Q2 \\
\hline Bolivia & 1990:Q1 & 2012:Q1 \\
\hline Brazil & 1990:Q1 & 2012:Q2 \\
\hline Belize & 2000:Q1 & 2012:Q1 \\
\hline Chile & 1989:Q1 & 2012:Q1 \\
\hline Colombia & 1994:Q1 & 2011:Q4 \\
\hline Costa Rica & 1991:Q1 & 2012:Q1 \\
\hline Dominican Rep. & 1992:Q1 & 2012:Q1 \\
\hline Ecuador & 1990:Q1 & 2012:Q1 \\
\hline El Salvador & 1990:Q1 & 2012:Q1 \\
\hline Guatemala & 2001:Q1 & 2012:Q1 \\
\hline Grenada & 2000:Q1 & 2012:Q2 \\
\hline Jamaica & 1996:Q1 & 2012:Q1 \\
\hline Mexico & 1990:Q1 & 2012:Q2 \\
\hline Nicaragua & 1994:Q1 & 2012:Q1 \\
\hline Panama & 1996:Q1 & 2012:Q1 \\
\hline Paraguay & 1994:Q1 & 2012:Q1 \\
\hline Peru & 1989:Q1 & 2012:Q2 \\
\hline Saint Lucia & 2000:Q1 & 2012:Q2 \\
\hline Uruguay & 1997:Q1 & 2012:Q2 \\
\hline Venezuela & 1993:Q1 & 2012:Q2 \\
\hline \multicolumn{3}{|c|}{ Middle East and North Africa } \\
\hline Jordan & 1992:Q1 & 2011:Q4 \\
\hline Morocco & 1990:Q1 & 2011:Q4 \\
\hline Tunisia & 2000:Q1 & 2010:Q4 \\
\hline \multicolumn{3}{|l|}{ South Asia } \\
\hline India & 1996:Q4 & 2011:Q4 \\
\hline
\end{tabular}

\begin{tabular}{|c|c|c|}
\hline & First observation & Last observation \\
\hline \multicolumn{3}{|l|}{ Sub-Saharan Africa } \\
\hline Botswana & 1994:Q1 & 2011:Q4 \\
\hline Mauricio & 2000:Q1 & 2012:Q1 \\
\hline South Africa & 1989:Q1 & 2012:Q2 \\
\hline \multicolumn{3}{|l|}{ High Income } \\
\hline Australia & 1989:Q1 & 2012:Q2 \\
\hline Austria & 1989:Q1 & 2012:Q1 \\
\hline Barbados & 1990:Q1 & 2012:Q2 \\
\hline Belgium & 1989:Q1 & 2012:Q1 \\
\hline Brunei & 2003:Q1 & 2011:Q4 \\
\hline Canada & 1989:Q1 & 2012:Q2 \\
\hline Croatia & 1993:Q1 & 2012:Q1 \\
\hline Cyprus & 1995:Q1 & 2012:Q1 \\
\hline Czech Republic & 1994:Q1 & 2012:Q1 \\
\hline Denmark & 1989:Q1 & 2012:Q1 \\
\hline Estonia & 1993:Q1 & 2012:Q1 \\
\hline Finland & 1989:Q1 & 2011:Q4 \\
\hline France & 1989:Q1 & 2012:Q2 \\
\hline Germany & 1989:Q1 & 2012:Q2 \\
\hline Hong Kong & 1989:Q1 & 2012:Q1 \\
\hline Hungary & 1995:Q1 & 2012:Q1 \\
\hline Ireland & 1997:Q1 & 2012:Q2 \\
\hline Island & 1997:Q1 & 2012:Q2 \\
\hline Israel & 1989:Q1 & 2012:Q2 \\
\hline Italy & 1989:Q1 & 2012:Q2 \\
\hline Japan & 1989:Q1 & 2012:Q2 \\
\hline Luxemburg & 1995:Q1 & 2012:Q1 \\
\hline Macao & 1998:Q1 & 2012:Q1 \\
\hline Malta & 1996:Q1 & 2011:Q4 \\
\hline Netherlands & 1989:Q1 & 2012:Q2 \\
\hline New Zealand & 1989:Q1 & 2012:Q2 \\
\hline Norway & 1989:Q1 & 2012:Q1 \\
\hline Poland & 1995:Q1 & 2012:Q1 \\
\hline Portugal & 1989:Q1 & 2011:Q4 \\
\hline Rep. of Korea & 1989:Q1 & 2012:Q1 \\
\hline Singapore & 1989:Q1 & 2011:Q4 \\
\hline Slovakia & 1993:Q1 & 2012:Q1 \\
\hline Slovenia & 1992:Q1 & 2012:Q1 \\
\hline Spain & 1989:Q1 & 2012:Q2 \\
\hline Sweden & 1989:Q1 & 2012:Q1 \\
\hline Switzerland & 1989:Q1 & 2012:Q1 \\
\hline Trinidad and Tobago & 2000:Q1 & 2012:Q1 \\
\hline United Kingdom & 1989:Q1 & 2012:Q2 \\
\hline United States & 1989:Q1 & 2012:Q2 \\
\hline
\end{tabular}

